\title{
Privately public seeds: competing visions of property, personhood, and democracy in Costa Rica's entry into CAFTA and the Union for Plant Variety Protection (UPOV)
}

\author{
Guntra A. Aistara ${ }^{1}$ \\ Central European University, Hungary and UN University for Peace, Costa Rica
}

\section{Introduction}

On October 7th, 2007, Costa Rica became the first nation in the world to hold a referendum on the ratification of a Free Trade Agreement. For Costa Rica's electorate, it was also the first national referendum in its 186 years of independence. The referendum on the ratification of the US-Central American Free Trade Agreement (CAFTA) was initiated by its opponents, and planned as the culmination of a four-year antiCAFTA struggle. But once the Supreme Tribunal of Elections approved the call for a referendum, it was organized - or the opposition would say, appropriated - by the Arias government.

Despite the efforts and hopes of opposition groups, voters approved the ratification of CAFTA, with a narrow margin of 51.6 percent in favor and 48.4 percent opposed, with electoral turnout at around 60 percent (Murillo and Venegas 2007). The defeat came as a shock to opponents because opinion polls had been showing a steady increase in opposition to CAFTA, with the final poll three days before the referendum showing a 12 percent lead in anti-CAFTA sentiment (Villalobos 2007a). Following the vote, there were many allegations of media bias, unlawful intervention by both Costa Rican and US politicians, and voting irregularities, but the result was not overturned (notlc.com). Costa Rica's President signed CAFTA into law in November 2007, but it still required a series of legislative changes by Parliament. CAFTA finally entered into force on January 1, 2009.

The referendum was described by government officials as a victory for democracy (Villalobos 2007b), but this view was not shared by the opposition (Chacon 2007). After the defeat, there was a drop in activity by opposing social movements, due to shock over the loss. Some in the environmental movement, however, wanted to begin working immediately to slow or stop the so-called "implementation agenda" of thirteen national laws that needed to be 'harmonized' to comply with CAFTA. One of these was the requirement to sign the Convention for Plant Variety Protection (UPOV) and to pass a national Law on Plant Variety Protection. The UPOV Treaty protects breeders' intellectual property rights to plant varieties, which activists see as simultaneously curtailing farmers' rights to continue saving and selecting their own seeds. Activists opposing the Free Trade Agreement proposed a new referendum on joining UPOV, signaling that for them questions of 'privatizing seeds' and 'patenting life' through the imposition of intellectual property rights, or converting seeds from 'nature' to 'property,' was deeply symbolic of the critical transformations in social relations implied by joining a Free Trade Agreement. ${ }^{2}$

Free Trade Agreements as economic instruments presuppose the existence of property to be traded for profit, therefore laws and regulations must be made and remade to facilitate the production of ever more tradable goods. Yet property scholars have noted that the concept of property should be explored as an ethnographic object itself, rather than taken for granted as a known entity (Verdery and Humphrey 2004). Illuminating studies of the reconfiguration of such seemingly recognized categories have emerged in postsocialist countries, where the sudden and radical change from planned to market economies resulted in "recombinant property forms" (Stark 1996 cited in Alexander 2004:253). I contend that the global trend towards entering Free Trade Agreements is accompanied by an equally significant transformation in property rights and social relations, thus these reconfigurations should also be examined along similar lines.

\footnotetext{
${ }^{1}$ Assistant Professor, UN University for Peace, San José, Costa Rica; and Post-Doctoral fellow, Central European University, Department of Environmental Sciences and Policy, Nador u. 9, H-1051 Budapest, Hungary. Email: guntra.aistara "at" gmail.com. This article is based on ethnographic research conducted in Costa Rica from 2005-2009, and follow-up research in 2011, including interviews with farmers, environmental activists, plant breeders and state officials; all translations are my own. A previous version of this paper was presented at the 2011 Nature, Inc. conference in the Hague, Netherlands. I wish to thank Michael Kennedy, Stuart Kirsch, Rebecca Hardin, Karen Hebért, and Hadley Renkin and anonymous reviewers for helpful comments on the paper. I am grateful for support from the Fulbright Hays Commission and the University of Michigan Rackham Graduate School, and the UN University for Peace. The writing of this article was sponsored by Central European University Foundation, Budapest (CEUBPF). The views expressed herein represent the ideas of the author, and do not necessarily reflect the opinion of CEUBPF or other funding sources. This paper appears in a JPE Special Section of Eric Wolf Prize papers edited by Joe Heyman.

2 I use the term 'seeds' to refer to all plant propagating materials.
} 
Furthermore, the effort to define seeds as commercially tradable goods allows us to recast the property debate in terms of political ecology. Political ecology seeks to anchor analysis of political economy, which deals almost exclusively with human and socioeconomic issues, in the ecology of the biophysical world (Bryant and Bailey 1997; Greenberg and Park 1994; Peet and Watts 1996). It also seeks to embed local conflicts surrounding control over natural resources into the nested regional, national and global politics and power dynamics with which they are inextricably linked (Greenberg and Park 1994; Wolf 1972). This combination provides a powerful lens through which to analyze the complexity of interactions across sectors and geographical boundaries through which struggles for natural resources occur.

Scholars of political ecology often presume that it is the role of researchers to show these connections, but I suggest that such analysis is not the exclusive domain of academics. Rather, groups involved in struggles for control over natural resources routinely foreground or deny various socio-ecological, political, or legal properties of resources at various temporal or spatial scales in order to justify their rights to claim these resources. Each such move to define resources through policies or practices thus has repercussions in terms of excluding other potential claimants of rights to access these resources. Through their actions, these groups offer competing visions of how a local resource should be defined and internationally connected; these visions can be understood as competing visions of political ecologies in practice. I will examine how elements of such a struggle were laid bare via debates over CAFTA and UPOV in Costa Rica.

Seeds are a crucial resource in the political economy of agriculture; struggles for control over seeds are grounded in precisely such debates over the significance of their ecological, social, and legal properties and local, national and global connections. Seeds are carriers of genetic information that is directly linked not only to the ecological conditions of production and reproduction, but also to the history of their management practices and social exchange relations (Aistara 2011). Therefore, by examining struggles over seeds through the lens of political ecology, I will show how the imposition of intellectual property rights to seeds is an attempt to 'remake' seeds. They move from being naturally and socially co-evolved, genetically mixed, locally adapted, and freely reproducible cultural objects to genetically pure, individually created, legally protected, and globally tradable products. This necessitates foregrounding certain types of seeds, classes of people, and kinds of social relations, and in turn excluding others.

I will show how this struggle over the political ecology of seeds happened between the proponents and opponents of UPOV in Costa Rica through parliamentary debates, the wording of legislation, and public debates in newspapers and activist campaigns. Following property scholars Verdery and Humphrey (2004), I will investigate here what happens to the 'things,' 'people,' and 'relations' that make up the property relations equation - in this case the seeds, the farmers and plant breeders, and the democratic processes through which this issue was decided. First I explain the UPOV convention and its reception in Costa Rica; then I turn to the transformations in conceptions of seeds, people, and democracy that have resulted from Costa Rica's entry into CAFTA and the process through which UPOV was ultimately approved. In the conclusion I reflect on what this struggle over seeds shows about the competing visions of the political ecology of property, personhood, and democracy in Costa Rica.

\section{Conventional wisdom: UPOV and its discontents}

In order to join CAFTA, seeds and plant varieties in Costa Rica must be legally transformed into property following the guidelines of the UPOV convention. First signed in 1961 by only six Western European countries, the UPOV Convention is designed to protect breeders' intellectual property rights, and standardizes procedures for registering new plant varieties. ${ }^{3}$ From the proponents' point of view, intellectual property rights for plant varieties are necessary to help stimulate scientific innovation in breeding and develop higher quality seeds; UPOV's stated mission is to "encourage the development of new varieties of plants for the benefit of society" (UPOV n.d.). UPOV allows breeders to collect royalty payments for up to 20 years for the use of seeds of protected plant varieties, and requires farmers to obtain permission from and/or provide payment to the breeder in order to use or reproduce the seeds. UPOV contains both a Breeders' Exception and a Farmers' Exception (discussed in greater detail below), through which signing countries may qualify these basic norms and make slight variations. There has been rapid growth in UPOV membership since the 1994 World Trade Organization (WTO) Trade Related Intellectual Property Rights (TRIPs) agreement required all members to adopt some form of plant variety protection (Jördens 2005).

The Convention was amended in 1972, 1978, and 1991, each time progressively restricting farmer seed-saving options. For example, the 1978 version of the Farmers' Exception allowed farmers to save seeds from protected varieties in order to reproduce them (for replanting). The 1991 version allows seed-saving only for production of subsistence food crops (for consumption), not for reproduction of the seeds themselves (Red

\footnotetext{
${ }_{3}$ In order to register and protect a new variety, it must meet four criteria: novelty, distinctness, uniformity, and stability. Small farmers' diversity-based planting practices and selection at the population level are incompatible with the criteria of uniformity and stability. Novelty and distinctness will be discussed below.
} 
de Coordinación en Biodiversidad 2007). Currently 69 countries are members of UPOV, but all countries joining now must adopt the 1991 amendments, which has made it increasingly controversial, because this is seen as endangering farmer seed practices globally. ${ }^{4}$ Joining the UPOV Convention also allows the sale of seeds and plant varieties protected in other member states, thus facilitating free trade in seeds.

In Costa Rica, supporters of UPOV see the use of improved, certified, seed of protected varieties as a way to increase seed quality and advance agriculture more generally. For the National Seeds Office, one of the main supporters of the Convention, one of the goals is to increase competitiveness and trade in agriculture:

In the current circumstances of globalization and the opening of markets, efficient and competitive forms of agricultural production become ever more necessary. ... It is an indisputable fact that seeds of good quality produced by research and development of varieties represent the strategic input par excellence that allows agricultural activities to be sustained, making significant contributions to improving the quality and profitability of production (Quirós O. and Carrillo A. n.d.)

For these writers, the approval of UPOV is part of a longer-term regionalization effort to standardize seed quality and eliminate trade barriers in Central America, as well as to facilitate trade internationally. It is a process that has been ongoing for at least fifteen years, but with continuous setbacks. Parliamentarians speaking in favor of UPOV in 2008 echoed similar sentiments about the importance of free trade in agriculture. Ofelia Taitelbaum Yoselewich, from the ruling party Liberación Nacional stated:

In order for the insertion into the global economy to be a source of prosperity, it requires that we export products and services with a high value added. ... In addition, in current times, modern agriculture is based in a highly dynamic seed agroindustry, and this, in turn, in programs of genetic improvement. Because of this, I affirm that the farmers will benefit from the approval of this UPOV convention (Asamblea Legislativa 2008).

In addition, proponents argue that that joining UPOV will help breeders be recognized for their efforts. Gabby Álvarez of the Ministry of Agriculture claimed that "the project in question intends to promote and contribute to the national seed industry and research in breeding, in order to [provide] a larger and better supply of varieties for use in the national agriculture [sector]" (Alvarez 2007). In these debates, proponents of UPOV prioritize export and large-scale commercial agriculture over that of small-scale producers. Thus, in the eyes of supporters, UPOV will help Costa Rica as a nation to sell value-added products on the global market; increase yields and quality; and promote their own plant breeding research.

Opponents have questioned these benefits. UPOV has been criticized by many activist groups domestically and internationally, such as Genetic Resources Action International (GRAIN), for giving plant breeders monopoly rights over genetic materials and contributing to genetic erosion by limiting diversity (GRAIN 1999b). In addition, these opponents point out that in many developing countries the majority of applications for plant variety protection are made for foreign-bred varieties, thus UPOV does not contribute to local scientific development, but rather to domination by multinational agroindustries (Red de Coordinación en Biodiversidad 2007). In fact, research in plant breeding has not been an agricultural priority in Costa Rica. There are seven public breeding institutes housed by Universities, four private, and one mixed public-private breeding institute. A total of approximately 60 new varieties have been developed in 50 years of breeding history (Saborio and Brenes 2005), therefore it is indeed likely that more foreign varieties than local ones will benefit from UPOV registration and protection in Costa Rica.

Opponents to the treaty have also argued that it is a "soft patent" on plants and seeds, and is thus in violation of the ethical principle opposing patenting life (GRAIN 1996). This relates to larger international debates about the moral principles and implications involved in designating intellectual property rights for living organisms (Brush 1999; Kirsch 2004; Cleveland and Soleri 2007). Opposition party members in Parliament, like Patricia Quiros, made this point very clearly when speaking against UPOV: "the rejection of the patentability of life and the generalized rejection by our people of intellectual property on living beings has been one of the main causes of the rejection of the principles of UPOV [in Costa Rica] until now" (Asamblea Legislativa 2008).

Indeed, concerns about UPOV were not new in Costa Rica, as the Legislative Assembly had already rejected joining UPOV twice in 1999 and 2002 (Rodriguez 2008). On those occasions, joining UPOV was proposed as a way to fulfill the requirement of the WTO TRIPS agreement to establish a mechanism for

\footnotetext{
${ }^{4}$ Countries that joined previously had a choice whether or not to adopt the 1991 changes. Some countries, for instance Norway, chose to remain with the 1978 version (GRAIN 1999b).
} 
protecting intellectual property rights on plant varieties. The Biodiversity Coordination Network, a group that had formed spontaneously in 1998 as a result of efforts to adopt a new Law on Biodiversity, argued successfully that UPOV was not the only way to meet the requirement, and proposed an alternate bill on plant variety protection in 2003. The new bill would meet the requirements of the WTO, but be less restrictive of farmer seed-saving than UPOV. ${ }^{5}$ The alternative bill had never been debated, and is unlikely to succeed, because Chapter 15 on intellectual property rights in CAFTA explicitly required joining UPOV, and there was strong political pressure to do this. Local opposition groups noted that the proposed Law on Plant Variety Protection was a mere copy of the UPOV Convention and made no attempt to take local conditions into account.

Furthermore, the opposition pointed out numerous ways in which UPOV contradicts specific national laws. The first is the Law on Biodiversity from 1998, which establishes 'community intellectual rights' over genetic resources and requires community consent prior to commercialization of biodiversity (GRAIN 1999b; Red de Coordinación en Biodiversidad 2007). Secondly, UPOV was seen to contradict the spirit of the 2007 Law on the Development, Promotion, and Support of Organic Agricultural Activities (henceforth Law on Organic Agriculture). The approval of the Law on Organic Agriculture had been a momentous victory for the Costa Rican Organic Agriculture Movement (MAOCO) because it was the culmination of a four-year process of designing and lobbying for the law. MAOCO consulted with farmers and lawmakers and hired lawyers to help them incorporate language into the bill that would support their views. Throughout the negotiations some minor points in the bill have been changed, but all of the most important elements were included in the final law.

Indeed, many farmers and activists commented that one of the most important elements of the law was the support it granted to farmers who wanted to continue using and protecting their own seeds. According to the law, the State is charged with the responsibility to protect farmers' rights to use, save, and exchange semillas criollas (Asamblea Legislativa de la Republica de Costa Rica 2007). Semillas criollas are seeds with a mixed or "creole" genetic heritage from generations of farmer selection and breeding. Semillas criollas and their exchange play an important role ecologically in Costa Rican organic farms, because continuous genetic mixing promotes higher resistance to diseases and pests, and renders seeds and plants better adapted to local conditions (Cleveland et al. 1994; Brush 1999; vom Brocke et al. 2003; Salazar et al. 2007). Yet semillas criollas may also sometimes incorporate genetic materials from modern varieties that would henceforth be protected. $^{6}$

The language of the Law on Organic Agriculture closely resembles that of the 2001 FAO Treaty on Plant Genetic Resources, which farmers' groups around the world have invoked to protect farmer seed-saving practices. Agricultural genetic diversity declined $75 \%$ in the $20^{\text {th }}$ century, and in situ (on-farm) conservation is crucial to preventing further genetic erosion (FAO 1993). This Treaty, however, ultimately leaves the protection of farmer seed practices up to the State, and has suffered from a lack of investment for implementation and enforcement (Kastler et al. 2007). Because Free Trade Agreements have higher standing than national law, activists from MAOCO and the Biodiversity Network feared that the while the Law on Organic Agriculture had established the State's role to protect farmer seed practices, joining UPOV could undo that protection.

\section{Sorting seeds}

How, then, do Free Trade Agreements and their associated legislation transform seeds into property, and what properties of the seed or plant variety must be foregrounded for this transition to take place? And how does this contrast with the characteristics that make seeds valuable to the organic farmers and the social movements opposing UPOV? While many discussions about the need for plant variety protection, cited above, invoke the issue of seed quality, I will argue that at the heart of this debate are also definitions of the authenticity and legitimacy of seeds and germplasm, which must be delineated in order to designate the most appropriate stewards of seeds as resources. I will trace how definitions of authenticity and legitimacy play out in the process of seed commodification in the implementation of UPOV in Costa Rica.

\section{Authenticity}

During debates about UPOV in Costa Rica, I had a conversation with Jorge, a representative of the National Seeds Office, the main implementation agency for the Convention. In light of farmers' fears that companies may seek to privatize their seeds, we spoke about what makes plant genetic material 'interesting' for the commercial sector. Jorge dismissed the farmers' fears, by describing to me the state of agricultural genetic resources in Costa Rica:

\footnotetext{
${ }^{5}$ Other countries in Latin America also developed their own interpretations of the minimum intellectual property rights necessary and passed alternative laws that are more liberal than UPOV towards farmers' rights (GRAIN 1999a).

${ }^{6}$ See Salazar et.al. (2007) for an analysis of the wide range of farmer breeding practices.
} 
Costa Rica has enormous potential in biodiversity and many things to discover, but in the agricultural sector, what is it that we use and where does it come from? The important products for food security - rice, beans, [corn] flour, potatoes, vegetables...[or the] economically important products- banana, coffee, sugarcane... where did these national varieties come from? The germplasm comes from Columbia, the Philippines, Asia. ... Never in the agricultural history of Costa Rica have we discovered something, and [it is] difficult [to imagine] to find anything that will support material for investigation for new varieties.

This perspective suggests a significant limitation on what types of genetic resources are considered valuable based on the 'authenticity' of the genetic material and a search for the original germplasm or 'urancestors' of plants. ${ }^{7}$ This complements the ideal of genetic purity of seeds imposed by seed legislation for seed certification (Aistara 2011). Such emphasis on historical ancestors and genetic purity parallels the search for the historical or 'real' as markers of authenticity in cultural realms (Lindholm 2008).

This view is not shared by all plant breeders in Costa Rica, however. For example, one group has been working on collecting wild potato varieties growing in Costa Rica for use in breeding local potato varieties that could compete with those bred abroad, despite the fact that the ur-ancestor of potatoes comes from far away in South America (Yao 2010). And while it is true that there will be more genetic variation and more crossing with wild relatives closer to the centers of origin of crop domestication (Brush 2000), one of the main reasons for in situ conservation, as complementary to ex situ conservation (in gene banks) is that it allows for the continuous evolution of the genetic material and adaptation to changing conditions, which is particularly important in the face of climate change. This renders locally adapted varieties just as important as the 'original' germplasm, but according to Jorge such characteristics do not hold the same value for the seed industry or for the state.

These characteristics, however, are extremely important for Costa Rica's organic farmers working with semillas criollas. The organic agriculture movement in Costa Rica has tried to consciously revalue semillas criollas, by organizing seed exchanges, publishing booklets featuring farmer knowledge on organic production, and encouraging farmers to create local seed sanctuaries. In many seed exchanges I saw farmers proudly displaying their seeds. The qualities that they presented as most valuable at such exchanges were their long history of family management of the seed stock, their own efforts to adapt the seed to local conditions, and a mixed genetic heritage that ensured the resilience of the seed to pests and diseases. Equally important was the role of seed exchanges in defining social kin networks. Costa Rican organic farmers had created new cultures of relatedness with their peers with whom they exchange seeds. Thus the genetic diversity of the seed stock is maintained by the exchange process within networks of kin and peers (Aistara 2011).

These qualities are reinforced by several clauses in the 2007 Law on Organic Agriculture that define semillas criollas as:

seeds that correspond to varieties cultivated and developed by agricultural persons and local communities. Independent of their origin, they are adapted to local agricultural practices and ecosystems (Asamblea Legislativa de la Republica de Costa Rica 2007).

This definition indicates that it is not only the genetic material itself that is of primary importance, but also the people, practices, and environment in which they are cultivated. This is not to say that the genetic material of semillas criollas is not at all important. The Law goes on to declare that it is the role of the State and its institutions to:

...promote, stimulate and protect the right of agricultural persons and organizations to access, use, exchange, multiply and save semillas criollas, with the aim of preserving the creole genetic heritage for the benefit of current and future agricultural producers (Asamblea Legislativa de la Republica de Costa Rica 2007). [emphasis added]

The combination of these two clauses reveals that according to this Law, the genetic heritage worth preserving is not limited to only the oldest crop ancestors, scientifically delineated stable varieties, or only 'high-quality' seeds, but rather to all the seeds and propagating material that local farmers have selected, preserved, and exchanged throughout generations. Furthermore, the local adaptation and genetic mixing are

\footnotetext{
7 There is a whole subfield of genetics that now uses molecular markers to search for genetic purity and for what is called 'authentic germplasm.'Authenticity is used to refer to both the origins of the sample, as well as a sample being true-to-type to the expected characteristics of the variety (Yao 2010).
} 
also crucial. Therefore the Law establishes the social relations surrounding production, reproduction, and exchange of seeds as the most important elements of the system, and relates them directly to the mixed genetic heritage of the seeds. This helps to maintain both agricultural and cultural diversity. These properties encoded in the law, then, are what make semillas criollas valuable to the organic farmers' movement, and what gives them, in the eyes of organic farmers and activists, the air of authenticity.

\section{Legitimacy}

In order for something to become property, it must be registered as such. Applying this principle to seeds raises many issues of legibility and legitimacy of germplasm, as well as its ideal type of management in public versus private hands, which is regulated by the UPOV Convention. Later in our conversation, Jorge concluded that semillas criollas managed by Costa Rican farmers would not be interesting for the seed industry because companies would already have access to most of the original genetic material in gene banks. And if there were any specific traits in farmers' varieties, like disease resistance, that would be interesting for the companies, they would only be interested in reproducing that one gene, and not the entire variety. Therefore, for Jorge, the removal of the genetic material from its place of origin and its placement into a public gene bank is the moment that legitimizes it as germplasm, and makes it further divisible to the gene level. This is an example of what Cori Hayden (2003) has called the 'publicization' of resources that she observed in bioprospecting in Mexico, where plants on the side of the road and available in public markets were more accessible and less 'messy' in terms of their implied property relations, and thus more attractive for bioprospecting.

It is important to examine the relationship between such publicization and privatization processes. Plant genetic resources have often been described as part of the 'common heritage' of mankind, and as being part of the global commons (Kloppenburg 1988; Brush 2005). Yet plant genetic resources do not fall into the typical 'tragedy of the commons' scenario (Hardin 1968), which portrays overuse as a problem for common pool resources (Chander and Sunder 2004). Boyle (2003:35) explains why the commons was considered an inefficient form of property management: "Before the enclosure movement, the feudal lord would not invest in drainage systems, sheep purchases, or crop rotation that might increase yields from the commons-he knew all too well that the fruits of his labor could be appropriated by others." With agricultural genetic resources in the public domain, the situation is quite the opposite in terms of investment in the resource. Individual farmers have been making improvements to the genetic resource over time, which has in turn benefited others in the community, who have then improved it yet again. Thus, rather than suffering from a lack of investment in the resource, which private management would improve, farmers have themselves improved it over time. The private sector, however, was not able to capitalize effectively upon these improvements before the imposition of intellectual property rights and the rise of biotechnology (Lewontin 1998).

Indeed, until plant variety protection and patents were imposed, plant germplasm was as an example of Drahos' 2006 concept of a 'negative commons,' where "resources are owned by no one, and therefore appropriable by anyone" (Roa-Rodriguez and Van Dooren 2008). Kloppenburg (1988) has argued that much of world agricultural history has in fact been based on appropriating this common heritage of germplasm from the global South for the benefit of the global North, through international collection and subsequent inclusion in public gene banks. Since the 1992 Convention on Biological Diversity (CBD), this public domain has been divided among sovereign states that have the responsibility for governing these resources (Roa-Rodriguez and Van Dooren 2008) and making them accessible to breeders.

The concern over the possibility of appropriation of farmer knowledge and seeds is acknowledged by UPOV. Varieties to be registered for protection must be 'novel' and 'distinct' from other varieties that are registered or that are considered 'common knowledge.' In theory, farmers could contest registered varieties as having been originally a result of their own selection:

In applying the notion of common knowledge in cases of dispute...UPOV members are recommended to be prepared to take into account not only knowledge that exists in documented form, but also the knowledge of relevant communities around the world provided that this knowledge can be credibly substantiated so as to satisfy the standard of proof of the civil law courts. ... This means, for example, that landraces which are capable of satisfying the definition of 'variety,' and which can in consequence be defined and propagated unchanged should be regarded as varieties of common knowledge for distinctness purposes (UPOV 2002).

In a well-known dispute over a patent for the Enola bean, a US company representative originally purchased the bean in a Mexican market, stabilized it as a variety, and obtained a patent. This would henceforth require all farmers (including the same Mexican farmers who had sold the bean) to pay royalties for its continued use. The patent was overturned as a result of cooperation with the FAO and the International 
Center for Tropical Agriculture, because the bean was already stored in their gene bank, which proved that it was already 'common knowledge' (RAFI 2000; Rattray 2002; Wilson 2008). In practice, however, for communities or farmers on their own to follow what varieties are being registered anywhere in the world and contest them "so as to satisfy the standard of proof of the civil law courts" is difficult, if not impossible, particularly if their varieties are not stored in any gene banks. Thus, the publicization of resources is a doubleedged sword, which can both facilitate appropriation and protect from it.

Ironically there is no centralized public gene bank in Costa Rica. Each public breeding institute has its own small collection, but there is no unified register, and farmers do not have information about what is contained in the collections. Therefore organic farmers in Costa Rica have begun making attempts to do their own cataloguing, keeping track of seed supplies at seed exchanges, and making a preliminary catalogue of available seeds, but progress is slow and dependent on outside funding and sufficient time, of which farmers have little. Yet these are also attempts to show that they are the rightful owners and managers of seeds. Farmers are wary of publishing their seed catalogues, because they feel that this would make the seeds more accessible to those who might seek to appropriate them. Even the University of Costa Rica, which houses the majority of public breeding institutes in the country, as well as two other public universities, testified against passing the Law on Plant Variety Protection and joining UPOV in 2008, based on similar concerns over the private appropriation of public knowledge (Asamblea Legislativa 2007). Chander and Sunder (2004:1345), citing Rose, have suggested, "It is a mistake to suppose that the public domain and private property are independent realms. Instead, the two are intimately intertwined, both historically and economically," and the "public domain often functions in service of property, not in opposition to it" (2004:1346).

Thus, we can conclude that in order to transform seeds or plant varieties from 'nature' to 'property,' they must first be considered old or authentic, then have been removed from the field and included in a public gene bank. Then are they ripe to be claimed by breeders to be reincarnated into tradable commodities. Meanwhile organic farmers, through their design of the Law on Organic Agriculture, have tried to position the authenticity of seeds as emerging from the mixed creole genetic heritage and adaptation to local environments, and their legitimacy from the continued selection and management of the seeds by farmers. The contest over the political ecology of seeds thus also involves a crucial division between definitions of breeders and farmers.

\section{Classifying people}

What are the consequences of this struggle over the redefinition of the authenticity and legitimacy of seeds by the proponents of UPOV? Is it the eventual privatization of seeds, as the farmers and activist groups fear? I suggest that it is not the seeds themselves that will get privatized, but perhaps more importantly, it is the knowledge surrounding seeds and the privilege of seed management that get appropriated through drawing a distinction between breeders and farmers. These privileges are codified in two special clauses in the UPOV Convention. The Breeders' Exception grants breeders special rights to use protected varieties to create new (protected) varieties. Meanwhile, the implementation of the Farmers' Exception in Costa Rica divides farmers along purely economic criteria, and does more to exclude them from seed management than to grant special privileges, which results in a redefinition of their personhood.

\section{Origin stories: evolution vs. creationism}

The issues of authenticity and legitimacy of germplasm are directly related to the question of the management of seeds as a resource. The focus on original germplasm simultaneously discounts the slow, incremental processes of 'guided evolution' that have been led by farmers over centuries since the time of the first domestication of these plants. In Costa Rica the Organic Law of 2007 had designated organic agriculture, and with it semillas criollas, as a matter of the 'public interest,' but left control over the seeds in the hands of the communities managing them. The debate over UPOV in Costa Rica was part of a larger debate over governance of resources by public or private interests. Farmers who had been actively involved in preserving agrobiodiversity were concerned about losing control over plant genetic resources.

For commodification of seeds and plant varieties to be effective, intellectual property rights must limit the number of potential 'investors' in the resource. Therefore it must be clearly identified who is making 'legitimate' improvements, or in this case, who counts as a breeder. The UPOV system was originally developed in a way that set it apart from patents, so that discoveries of natural genetic mutation or crosspollination, often made by farmers, could also be protected, which was not possible under patent law. Subsequently wording in UPOV was changed, however, to include 'discovery and development' rather than just discovery (UPOV 2002), narrowing the interpretation of breeding to fit laboratory settings more readily than farmers.

\footnotetext{
${ }^{8}$ The UPOV document notes that the French term originally used is obtentuer which can be translated more literally to plant improver than breeder (UPOV 2002). In Spanish, the term used is mejoramiento, which is literally 'improvement.'
} 
Yet all newly developed plant varieties, registered and protected by breeders under UPOV, have been created using raw materials that are a product of both natural selection and selection by farmers. Van Dooren (2008) has an insightful analysis of the fetishism of the seed that results from foregrounding the 'invention' of seeds or varieties by breeders, rather than the intricate webs of farmer and non-human interactions that have come before them, and on which they depend. He observes that this creates a division between breeders as representative of 'culture' versus farmers who remain trapped as a part of 'nature.' This prioritizes the investments of individuals or institutions at the present and future over historical ones.

This exclusion of farmers from the category of breeders is not accidental. Kloppenburg (1988) has documented the many steps in the commodification of seeds that took place through the gradual incursion of private interests into public agricultural research, transforming breeding into a form of primitive accumulation in the $20^{\text {th }}$ century. He contends that the imposition of intellectual property rights involves a misapplication of Marx's labor theory of value, because it separates breeders' labor as 'real' work, while discounting the labor of farmers over many generations, despite the enormous improvements in plant resources achieved during this time.

This interest in the 'creation' of new plant varieties by breeders, compounded by the search for 'authentic' or 'original' germplasm mentioned earlier, results in the dual fetishization of the moment of creation over evolution. This is necessary for the commodification of seeds as alienated, isolated elements of the agricultural system. Removing seeds from circles of seed exchange among kin and peers, the process that facilitates genetic exchange, re-conceives them as genetically pure objects whose genealogy is traceable by scientists. Practically, this means that seeds must thus be purchased anew and reproduced as true to their original form as possible, rather than allowing for further evolution in field conditions (Aistara 2011).

Jorge in Costa Rica also explained to me how farmer breeding is an entirely different activity than technical, precise, and efficient breeders' work:

The farmer is usually not going to be involved in a program of genetic improvement per se; the farmer makes a more intuitive improvement, from observing plants, identifying the best onesit is a more informal program, to improve and to get good seeds. They can obtain very interesting things, but more rustic ones more adapted to the conditions of use...but not for the seed market.... There are some activities where farmers may have more varieties, because they are not interesting for the industry. But this is the only reason, not because they are more efficient, and this is the truth.

This discounts farmers' breeding methods as antiquated, inefficient, and emotional, and ultimately uninteresting for the seed industry. Yet this is not a view that is necessarily backed by all breeders. One breeder at a public institute told me that there is no question that farmers manage an incredibly rich diversity of varieties of crops, but the problem is only that they have never been systematically catalogued. He also had no doubt that companies would, and in fact already were, using various methods to collect this germplasm and use it for their own purposes in the development of new varieties. The breeder's observation raises the question of why these countless varieties managed by farmers don't 'count' as germplasm, as well as going to the heart of why they are potentially appropriable by others.

\section{The privately public life of germplasm}

In the implementation phase of UPOV, the definition of breeder discussed above becomes extremely important, because UPOV contains a Breeders' Exception, which allows breeders public access to use seeds of protected varieties if it is for research purposes, in order to develop a new variety. At the same time, the Convention denies this same right to farmers who may want to cross their own seed with a protected variety in order to improve it, because they do not qualify as breeders. Thus, what is in the public domain and 'free' for the advancement of scientific knowledge for some, becomes a criminal offense for others. The management of public germplasm and knowledge becomes a nationally and internationally protected private privilege, which translates as the right to have one's creativity and efforts recognized. The result is that UPOV, through redefining the authenticity and legitimacy of seeds, and redrawing the boundary between breeders and farmers, makes seeds accessible as property only to an exclusive group of privileged breeders. Thus through UPOV, the public domain becomes restricted only to those who are considered breeders, creating what I call 'privately public seeds.'

Furthermore, the 1991 introduction of the category 'essentially derived varieties' in UPOV broadened the reach of plant variety protection by extending breeders' rights to claim royalties also for all varieties which are closely related to the originally protected variety (Salazar et al. 2007; Roa-Rodriguez and Van Dooren 2008). This will result in further concentration of market share in the hands of fewer breeders. 


\section{From farmers' exception to farmers' exclusion}

If breeders win such exclusive rights through UPOV, what will be the fate of the farmers? I will argue that the debate over UPOV and its implementation reveals a larger debate about the role of farmers in society: as producers or consumers, as a social class, and as law-abiding or law-transgressing citizens.

First, if breeders become the owners of seeds as (intellectual) property, it stands to reason that someone must become the consumer. After UPOV passed, activists in Costa Rica pointed out with indignation that seeds were referred to as 'the finished product' and asked incredulously:

Who 'finishes' the product? The seed companies like Monsanto, who now have almost a monopoly on the sale of seeds in Central America? Since when is the farmer not the producer par excellence and...the seeds the fruit of his or her tenacious daily work? (Red de Coordinación en Biodiversidad 2008).

They thus revealed that, if according to UPOV breeders are named discoverers and entrepreneurs, farmers become mere 'end-users' and 'consumers' of seed (Red de Coordinación en Biodiversidad 2008), entailing a fundamental transformation of identity.

Furthermore, farmers and activists were concerned that small farmers in particular would lose their right to keep saving their own seeds. In order to address this concern, countries signing the UPOV Convention may (but are not required to) also make exceptions for farmers to reuse their own seed under certain circumstances under a clause called the Farmers' Exception. ${ }^{9}$ Because of this exception, Jorge explained to me that small farmers working with semillas criollas needn't worry, that they were not the target of the UPOV legislation, and that they would be able to continue with their work:

There are farmers who save their own seeds and use their own [seeds]- this is no problem and is not illegal. On the other hand, there is a clandestine seed market...it's not very large, but it exists. The Office can intervene if it detects an irregular commercial situation. Usually, those who do this are doing it without bad faith, or intentions, but [there are] others who know what they are doing and have goals of profit and are simply trying to compete with those who comply with the quality standards, who are under the process of supervision.

Thus Jorge insists that UPOV is intended more for commercial and industrial agriculture and suggests that there might be space for defining smallholders for whom the Farmers' Exception would apply. Parliamentarians speaking in favor of joining UPOV in 2008 echoed similar reassurances that the Farmers' Exception would let smallholders continue with seed-saving and exchange.

As promised, in the Costa Rican Regulations for the implementation of the Plant Variety Protection Law, published by the Ministry of Agriculture in January 2010, smallholders are indeed defined and granted separate rights, presumably to delineate who constitutes a threat of creating a 'clandestine seed market.' The Farmers' Exception states that:

Article 25: Breeders' rights do not apply for cases of private use for non-commercial and nonprofit use, like planting for family consumption or at the hobby level.

Article 26: It is considered that breeders' rights are not infringed upon if small or medium farmers save and resow in their own land a protected variety (Ministerio de la Agricultura y Ganaderia 2010).

At first this seems a welcome turn, indicating that even if farmers cannot select seeds and breed their own varieties using protected varieties, at least they are allowed to continue resowing them. Yet the devil is in the details. The state Regulation goes on to define small and medium farmers for whom the exemption allowing the re-use of seeds would apply:

Article 27: Small and medium farmers are those who:

- dedicate more than $75 \%$ of their time to farming;

- their labor is individual or with members of their family, contracting outside labor only for specific jobs;

\footnotetext{
${ }^{9}$ There is great variety in how broadly this exception is used in different countries. For example, the Netherlands has an exception for certain crops, such as wheat, whereas other countries may have none (GRAIN 1999b).
} 
- their socio-economic raison d'être is oriented fundamentally toward guaranteeing the subsistence of the nuclear family;

- their gross annual income from agriculture is not higher than the amount payable annually to an unskilled laborer according to official prevailing wage scales (Ministerio de la Agricultura y Ganaderia 2010).

What are the consequences of this definition? First, it is quite likely that farmers making no more profit than the minimum wage of unskilled laborers would in fact have to seek a second source of income from another job to survive, yet this action would disqualify them from the Farmers' Exception. To claim the Farmers' Exception, one must be a small or medium size farmer, yet to meet these criteria one is doomed to be, and more importantly, remain, poor. Thus, the Farmers' Exception is more of a 'breeders' charity' or alms for the poor, or could more aptly be renamed the 'Farmers' Exclusion,' since most people who want to be farmers for a living would not meet these criteria.

By enumerating these conditions to claim the Farmers' Exception, the Plant Variety Protection law in effect redefines farmers, and their rights, along purely economic criteria. This definition, then, also redefines the fundamental personhood of farmers. Farmers become proletarianized as laborers, and unskilled ones at that! If the legislation redraws lines between public and private domains and defines who has access to seeds for breeding, it also does something more. It determines the class structure surrounding agriculture and the destiny of farmers as the underclass.

This raises broader questions surrounding the role of intellectual property in defining class relations. Lewontin (1998) has argued that biotechnology and patents on seeds are a means to proletarianize farmers and capitalize on hitherto difficult-to-control resources. This is consistent with Giddens (1971) and others who remind us that social classes are determined primarily by property relations, only in this case, farmers as a class are being defined on the basis of a lack of registered intellectual property. It is access to this intellectual property over seeds, rather than capital, that ultimately governs the means of production.

The personhood of farmers is also affected in another way, with questions raised about farmers' honor and the criminalization of their traditional agricultural practices. In a debate that lasted several months in the Opinion pages of the national newspaper La Nación, geneticist J. Lobo and forest engineer M. Quirico pointed out that for farmers following the new Law, giving up the right to work with their own seeds would be worse than going to jail (Lobo and Quirico Jimenez 2007b). To this, a representative of the Ministry of Agriculture replied that "observing the [law] on plant breeding is not worse than jail; to think this is to think that our farmers will be transgressors of the law, something which will not happen, because their nature is to be honorable." (Alvarez 2007). Thus, farmers are also redefined as those who follow the law (unquestioningly), and those who would dare transgress such laws are excluded from the designation 'our farmers.' Yet Lobo and Jimenez answered thus: "Because we know the farmers, we know they are honorable and not delinquent by nature, but they may be converted into delinquents with the creation of a new unjust concept: the use of 'pirate plants"' (Lobo and Quirico Jimenez 2007a). They thus signal that the new Law has the potential to delegitimize and criminalize certain seeds, plants, and farmers in very powerful ways.

This view of farmers as consumers of seeds and doomed to be terminally poor (and/or criminals) contrasts sharply with the vision of the Costa Rican Organic Agriculture Movement and the 2007 Law on Organic Agriculture, which specifically recognizes the role of farmer-experimenters, who innovate on their farms and bring this knowledge further through networks such as campesino a campesino (farmer to farmer), not only in the area of seeds, but also concerning other agroecological practices. For their part, some public breeders were ambivalent about the stark division between breeders and farmers. One breeder acknowledged that farmers have a lot of skills and knowledge that have made it easy to work collaboratively to reproduce high quality seeds on their farms. He was skeptical about the amount of financial benefits public breeders in Costa Rica might obtain from registering their varieties, though after the law had passed they would be willing to try. These redivisions of people, however, are necessary in order to determine the legitimate managers of the authentic seeds as genetic resources, to be traded as property.

\section{Trading relations}

Having examined debates over the reconfiguration of seeds as the 'things' and farmers and breeders as the 'people,' I now turn to the process through which UPOV and the associated national legislation were approved. This allows reflection on the 'social relations' of these new property regimes. Just as the farmers were actually excluded through the Farmers' Exception, that was supposed to protect their rights, 'the people' were effectively excluded from decision-making on UPOV by the way the national referendum on the issue was resolved, even though it was supposed to give them a voice.

\section{Debating democracy}


On the eve of entry into force of CAFTA in January 2009, a US Embassy cable, later made public by Wikileaks, concluded: "The CAFTA telenovela [soap opera] remains a case study in dysfunctional democracy; the agreement required a national referendum and over three years of on-again, off-again legislative action during two Costa Rican administrations to come to fruition" (US Embassy San Jose 2009). The story of CAFTA in Costa Rica was indeed drawn-out and contentious. But this disparaging statement by a foreign power raises the question of whether the fact that strong opposition blocked approval of CAFTA for so long signals a functional or a dysfunctional democracy, especially in important decision-making matters like entering a Free Trade Agreement. This can be further investigated by looking at the fate of the proposed referendum on UPOV in Costa Rica.

In November 2007, several people from FECON (The Costa Rican Federation for Environmental Conservation) and the Biodiversity Coordination Network made an official application to the Supreme Tribunal of Elections to request the initiation of a referendum on the UPOV Convention and the additional required Law on Plant Variety Protection. In December, they received approval to initiate the process, and were required to collect a total of $5 \%$ of the electoral roll or 133,000 signatures within a period of nine months for the referendum to go forward. The victory of the pronouncement was dampened, however, by the numerous caveats to this decision. The legislative process of debating and voting on the bills would not be halted during the signature collection period. This meant that if the bills passed to a vote before the ninemonth signature collection period ended, the signatures would be invalidated. Furthermore, the new referendum could not be held sooner than one year after the previous referendum, or in October 2008 . $^{10}$

These conditions made the new referendum process lose much of its meaning and caused internal discussions among activists about the wisdom of proceeding with a process that was likely going to be cut short. ${ }^{11}$ Nevertheless, they decided to proceed in order to inform people about UPOV and show the government that there were still many people who did not agree with CAFTA and the implementation agenda. In addition they hoped it would expose the fact that the referenda regulations were stifling, rather than promoting democratic processes. Signature collection began in late January 2008, and by March when the bill was about to go to a vote, activists had collected nearly 80,000 signatures. They held a press conference requesting the Legislative Assembly to halt the legislative process. Photographed behind stacks upon stacks of signature sheets, activists emphasized that never before in the legislative history of Costa Rica had so many people signed a petition to stop a bill. Nonetheless, the UPOV Convention was approved on April 15, 2008. By this point 103,751 people had signed in support of initiating a new referendum, collected in a mere three months by patriotic committees and environmental activists throughout the country. The required 133,500 signatures (plus several thousand extra in case any were disqualified) were submitted one month later, but were no longer accepted (Fecon 2008).

This story is unique because UPOV is not necessarily a straightforward issue for a referendum, and indeed many observers dismissed it as too technical to be effectively decided by 'the people.' How, then, did the organizers convince over 130,000 people to sign for a referendum on UPOV? Julia Paley and colleagues in an edited volume on democracy (Paley 2008) have observed that in discussions about democracy, a preexisting notion of 'the people' is often taken for granted, rather than acknowledging that 'the people' are constituted through political action. The attempted UPOV referendum was just such an example of constituting 'the people.'

On December 31, 2007, after the court made its pronouncement that it would allow the UPOV referendum, a US Embassy cable, also later released by Wikileaks, proclaimed: "With sufficient discipline and focus in the legislature, the UPOV maneuver should not be more than a distraction for the GOCR [government of Costa Rica]" (US Embassy San Jose 2008). Thus, skeptics believed that the UPOV referendum was never a very real threat to CAFTA. Yet as the signature collection showed, many more people were constituted by this technical proposal than the governments of the US or Costa Rica thought possible.

This was largely due to the hands-on approach by the activists. One organizer commented that when you tell people that "UPOV stands for plant variety protection- it sounds beautiful...of course people want to protect the variety of plants!" Because of the deceptively nice title, he told me, the principles of UPOV took a lot of explaining. A representative of Fecon, Mario, pointed out that once they did start explaining, signature

\footnotetext{
10 This was because the collection process had been approved for holding a referendum on a bill, but if the Legislative Assembly voted, the bill would become a law, requiring a new referendum procedure to be initiated. The ruling also stated that because the Law on Referenda allows only one referendum per year, it could not be held earlier than October 7, 2008, or exactly one year after the CAFTA referendum, which was much after the proposed debate and vote on UPOV in the Legislative Assembly.

11 Many felt disillusioned and disenfranchised with what they considered the un-democratic process of the CAFTA referendum that they felt they could not support a new referendum process, but others believed it would help to revitalize the opposition movement.
} 
collection had not been difficult, because many of the arguments against UPOV were completely logical to Costa Ricans:

There are three to four basic topics that seem logical - or illogical. How can it be possible that a farmer has to pay for a seed that the community had been improving for one hundred years, because some company changed something in it, patented it or got breeders' rights, as the law says, and now [the farmers] have to pay? In addition, they can't save the seeds like they've done their whole lives. For a pueblo (people) that is medio-campesino (half-peasant) like in Costa Rica, this is not logical.

Thus, Mario emphasized that in Costa Rica it was unimaginable that farmers would not be allowed to save their own seeds, and people rallied against the idea of 'privatizing life.' This proved an effective slogan to position these national values against the interests of the US and transnational companies. Through this, the pueblo medio-campesino was constituted from a group of people who had likely never before heard of UPOV.

There was also a growing sense of offense and indignation on the part of the environmental activists over the way the political processes governing CAFTA, the implementation agenda, and passage of UPOV had been conducted. The negotiators of CAFTA had originally promised the Biodiversity Coordination Network that they would not renegotiate UPOV, because it had already been rejected twice, but did not comply with this promise (Red de Coordinación en Biodiversidad 2004). Furthermore, the Biodiversity Coordination Network was not invited to testify in the Agricultural Committee about the bill as it was being discussed, until after the first vote, and the text was changed with the addition of 23 new articles in midnegotiation. One of the changes eliminated the section that would have prohibited variety protection for genetically modified organisms (Red de Coordinación en Biodiversidad 2007). All of this led the activists to suspect dirty politics.

In a final set of ironies, in a series of last minute legislative changes as part of the implementation agenda, the Biodiversity Law of Costa Rica was changed by Executive decree (Arias Sanchez 2008), weakening the clause on the protection of community rights that would require consent from farmers' or indigenous communities before commercializing natural resources. The opposition Parliamentarian Jose Merino wrote, "The worst of it is that during the debates about CAFTA, COMEX [the negotiating agency] told the Costa Ricans that traditional knowledge would not be affected precisely because of the existence of this article, which they are now eliminating" (Merino del Rio 2008). Paradoxically, the Biodiversity Law, and the consultative process through which it had been originally developed, earned Costa Rica an international award in 2010 at the conference of the Convention on Biodiversity. Activists decried the award, stating that it reflected Costa Rica's doublespeak of projecting a conservation-focus to the outside world, while hacking away at the law on the domestic level (Zueras 2010).

By what criteria, then, should we judge the 'dysfunctionality' of a democracy? By the length of time and repeated attempts it takes to get to the outcome favored by those in power? The telenovela of UPOV was more slow-motion than that of CAFTA, but perhaps even more dramatic in its details. The lesson appears to be, if at first you don't succeed, try, try again. It took ten years, the introduction of UPOV on three different occasions in the Legislative Assembly, exclusion of the most contentious groups from consultations, the introduction of 'fast track' procedure to limit the amount of parliamentary debate, passage of a free trade agreement, an aborted referendum, and two presidential decrees to include issues that were too controversial to put up before parliament, in order to finally make seeds 'privately public' tradable commodities. After CAFTA's entry into force, the US Embassy asked itself: "And what will we do with all our 'free time' now that CAFTA is completed?...There is plenty left to do as we help Costa Rica's democracy better deliver for its people" (US Embassy San Jose 2009). The question remains: which people?

\section{Selected futures}

One term for breeding is 'selection,' and in fact, we see in the controversy surrounding the attempted UPOV referendum that the making of property requires careful selectivity applied not only to seeds, but also to people and social relations. On one hand, supporters of CAFTA felt indignant that the opponents of UPOV persisted in their struggle even after the fate of CAFTA had been decided by a referendum. In their eyes, the matter should have been closed once and for all, by the institutionalization of CAFTA into law, and the selection of the US as their trading partner for a better future. Comaroff and Comaroff (2000:328) have described one of the key elements of contemporary capitalism as being fetishism of the law, as the instrument that can level out incommensurable differences: "Like all fetishes, the chimerical quality of this one lies in an enchanted displacement, in the notion that legal instruments have the capacity to orchestrate social harmony."

We see such trust in the law in Jorge, who believes that all problems or lacunae in the law can simply be addressed by another law or treaty, through which eventually everyone's rights will be protected. For instance, he commented that if the prices set on seeds turn out to be too high, the consumer protection agency 
should be involved to regulate them. He pointed out, however, that the purpose of biodiversity is to be used, and that biodiversity laws must regulate access, but that transnational companies have an important role to play in the use of biodiversity:

If we are realistic, there are many products that will not be developed by Ministries of Agriculture or Health or small companies, which will probably be developed by transnationals that have technological and economic possibilities to develop them. And this isn't bad, as long as the raw materials have acceptable benefits - so the society benefits. Some people might say, 'but look, the transnationals will get the benefits.' But it would not worry me if they can find a cure for Alzheimer's or for cancer - the country will benefit economically and in other ways like technology transfer.

Such compartmentalization of the world, with an ultimate trickle-down effect of benefits is also echoed by some Parliamentarians. For instance, Janina Del Vecchio stated in an opinion piece in La Nación, "This law [UPOV] is best understood from the perspective of a global world that universalizes knowledge and its derivatives, where some countries provide the basis of research, others the research, the knowledge, and the technology, and as a result, everyone benefits from the research process" (del Vecchio U. 2007).

Yet this also reflects an entirely different view of property, captured in Locke's interest in defending property rights: "[Locke] was also justifying European conquest of the New World on the argument that Europeans could exploit the Americas more effectively than the native peoples because the Europeans would create private property in land and improve it, something the natives did not do" (Humphrey and Verdery 2004:4). Similarly, supporters of UPOV believe that ultimately, even if it is not Costa Rican farmers or breeders who will develop new products, that the ultimate benefits of free trade will be for the greater common good. Therefore global trade must be foregrounded over local exchange, and laws must be put in place to facilitate this process.

This view contrasts with the common assumption that free trade implies deregulation. Rather, Jorge sees UPOV as part of a tidy and legalistic world, in which all wrongs can be righted by another national level law or a new international convention, rather than promoting free trade in the laissez-faire sense of the term. From the perspective of its supporters then, UPOV is only one piece in a larger mosaic of laws and treaties that will govern people's and companies' behavior and give Costa Rica better footing in the unavoidable advance of technological progress.

According to the opponents of UPOV, however, laws can only be as good as the system that produces them. And to them, the democratic institutions through which the questions of CAFTA and UPOV were decided were highly selective in terms of which voices they allowed to be heard, and which they silenced. The attempted UPOV referendum, like the CAFTA referendum, was not successful in its outcome, but was undertaken in order to challenge the definition of democracy of the political system currently in place. For the farmers and environmentalists the questions of seeds and UPOV were important on two levels. First, in the moment of a crisis of democracy, the supporters of the referendum saw it as a demonstration of the selfdetermination of the voters, on behalf of the pueblo medio-campesino. Rejecting UPOV would be a way of demonstrating national sovereignty and ensuring food sovereignty. On a higher level, the process was related to the idea of public control over information. Mario (representative of Fecon) expressed a broader critique of the much-idealized tradition of democracy in Costa Rica:

Democracy is a tradition- very much just on paper. There is not democracy in the media, there is not access to information. Without media democracy there is no political democracy, because it has no meaning... For me this is the central issue- the issue of information. Because of this I think the campaign was successful, because it informed [people] in an unconventional way. By asking for your signature - you can give [it] to me or not - but you listened to what I had to say.

The emphasis on the importance of the process, rather than outcome of the referendum, shows that circulating ideas and engaging people in spreading the word, mouth-to-mouth, was crucial, and parallels in many ways the circulation and exchange of seeds, from hand-to-hand. Yet from the perspective of US observers, all of the opposition's attempts to organize a referendum were "no more than a mere distraction." 


\section{Conclusion}

These struggles were not easy for any of the parties involved, and their outcomes were far from predictable. While activists opposed to CAFTA and UPOV focused on the ecological issues surrounding the genetic diversity of seeds and the rights of farmers propagating and selecting them, proponents of making seeds an object for international trade emphasized that they must be legally registered and protected entities, held at the national scale in a gene bank, from whence they may enter global circuits of circulation. In all cases, the conflicts over seeds required definitions and redefinitions of seeds, farmers, breeders, and democratic processes. Within the social imaginary of the organic movement, seeds should be a public good, under community control, farmers should be experimenters and producers, and democratic processes must be participatory. For the proponents of UPOV, however, the registration of seeds and protection of plant varieties fits into a larger imaginary where national laws and international treaties govern rights and relationships among people and states, as a way of ensuring global progress and development through trade.

Analyzing the outcome of the CAFTA and UPOV referenda as a political ecology case study in retrospect, the story seems quite familiar: government proponents of international treaties had more resources at their disposal and were thus able to influence the course of events, meaning that the ecology of seeds and the social systems of local farmers were subordinated to the interests of big business and big politics. Only old, authentic seeds kept in public gene banks count as legitimate germplasm; only those who can create something new in the laboratory, with exclusive public access to germplasm, count as breeders; and only those groups that support the overall goal of increasing trade will be free to participate in the negotiations.

Yet I believe the story is more complicated than that. The actions by both sides were an effort to define the politics and ecology of seeds in practice, not only in Costa Rica, but globally. They each paint a different picture of connections, exclusions, and global positionings. And these contests over definitions of the political ecology of seeds are far from over, because it will be the practices on the ground, rather than the legal documents on file, that actually determine the future of seeds. As one farmer put it, "Seeds are ours, yours, everyone's. You can take these seeds and plant them. There is a threat now of patents and that you can go to jail. But if I have to put them in a little box and hide them until I can take them out again, I will do it." ${ }^{12}$

\section{References}

Aistara, G. 2011. Seeds of kin, kin of seeds: the commodification of organic seeds and social relations in Costa Rica and Latvia. Ethnography 12(4):490-517.

Alexander, C. 2004. Value, relations, and changing bodies: privatization and property rights in Kazakhstan. In K.Verdery and C.Humphrey (eds.) Property in question: value transformation in the global economy. Oxford and New York: Berg. Pp.251-273.

Alvarez, G. 2007. Registro de variedades vegetales. La Nación. 31 October 2007. San José. [accessed September 10 2011] http://wvw.nacion.com/ln_ee/2007/octubre/31/opinion1297618.html

Arias Sanchez, O. 2008. Decreto n ${ }^{\circ}$ 34958-MINAET-COMEX. San Jose.

Asamblea Legislativa. 2007. Acta de la sesión ordinaria $n^{\circ} 68,21$ de febrero de 2007, Audiencia: Consejo Universitario de la UCR. San Jose, Costa Rica: Comisión Permanente De Asuntos Agropecuarios y Recursos Naturales.

Asamblea Legislativa. 2008. Acta de la sesión plenaria no. 167, martes 15 de abril de 2008; Segundo periodo de sesiones extraordinarias, segunda legislatura. San José, Costa Rica.

Asamblea Legislativa de la Republica de Costa Rica. 2007. Ley para el Desarrollo, Promoción y Fomento de la Actividad Agropecuaria Orgánica nº 8591 del 14 de agosto 2007. La Gaceta. San José, Costa Rica.

Boyle, J. 2003. Second enclosure movement and the construction of the public domain. Law and Contemporary Problems 66: 33-74.

Brush, S. 1999. Bioprospecting the public domain. Cultural Anthropology 14(4):535-555.

Brush, S. (ed.) 2000. Genes in the field: on-farm conservation of crop diversity. Rome, Ottawa, Boca Raton: International Plant Genetic Resources Institute, International Development Research Centre, and Lewis Publishers.

Brush, S. 2005. Farmers' rights and protection of traditional agricultural knowledge. Washington DC: International Food Policy Research Institute.

Bryant, R., and S. Bailey. 1997. Third world political ecology. London: Routledge.

Chacon, V. 2007. Hubo una afrenta a la democracia. Semanario Universidad. San José, Costa Rica. 25 October. Pp. 9.

\footnotetext{
${ }^{12}$ Quoted also in Aistara 2011.
} 
Chander, A, and M. Sunder. 2004. The romance of the public domain. California Law Review 92(5):13311374.

Cleveland, D., and D. Soleri. 2007. Farmer knowledge and scientist knowledge in sustainable agricultural development: ontology, epistemology and praxis. In P.Sillitoe (ed.) Local science vs global science: Approaches to indigenous knowledge in international development. New York and Oxford: Berghahn Books.Pp.209-230.

Cleveland, D., D. Soleri, and S.E. Smith. 1994. Do folk crop varieties have a role in sustainable agriculture? BioScience 44(11):740-751.

Comaroff, J, and J.L. Comaroff. 2000. Millennial capitalism: First thoughts on a second coming. Public Culture 12(2):291-343.

del Vecchio U., J. 2007. Ley de obtenciones vegetales. La Nación. 5 November 2007. San Jose, Costa Rica. [accessed 1 May 2011] http://wvw.nacion.com/ln_ee/2007/noviembre/05/opinion1303963.html

FAO. 1993. Harvesting nature's diversity. Rome: FAO.

Fecon. 2008. Campaña dejó muchos frutos. Yo Firmo. [accessed August 30 2008] http://yofirmo.com/index.php?optioncom_content\&task=view\&id=106.

Giddens, A. 1971. Capitalism and modern social theory: an analysis of the writings of Marx, Durkheim and Max Weber. Cambridge: Cambridge University Press.

GRAIN. 1996. UPOV: Getting a free TRIPs ride? Seedling 11 June 1996.[accessed 1 May 2011] http://www.grain.org/article/entries/321-upov-getting-a-free-trips-ride

GRAIN. 1999a. Beyond UPOV: Examples of developing countries preparing non-UPOV sui generis plant variety protection schemes for compliance with TRIPs. Barcelona: GRAIN.

GRAIN. 1999b. UPOV on the war path. Seedling 25 June 1999.[accessed 1 May 2011] http://www.grain.org/article/entries/257-upov-on-the-war-path

Greenberg, J.B., and T.K. Park. 1994. Political ecology. Journal of Political Ecology 1(1): 1-12.

Hardin, G. 1968. The tragedy of the commons. Science 62:1243-1248.

Hayden, C. 2003. When nature goes public: the making and unmaking of bioprospecting in Mexico. Princeton: Princeton University Press.

Humphrey, C., and K. Verdery. 2004. Raising questions about property. In K.Verdery and C.Humphrey, (eds.) Property in question: value transformation in the global economy. New York: Berg. Pp. 1-25.

Jördens, R. 2005. Progress of plant variety protection based on the international convention for the protection of new varieties of plants (UPOV convention). World Patent Information 27:232-243.

Kastler, G., M. Rahmanian, P. Mooney, D. Pelegrina, A. Onorati, and A. Mushita. 2007. Farmers call for suspension of seed treaty. Press release from FAO civil society organizations. Rome.

Kirsch, S. 2004. Property limits: debates on the body, nature, and culture. In E. Hirsch and M. Strathern (eds.) Transactions and creations: property debates and the stimulus of Melanesia. Oxford: Berghahn. Pp 21-39.

Kloppenburg, J. 1988. First the seed: the political economy of plant biotechnology, 1492-2000. Cambridge: Cambridge University Press.

Lewontin, R.C. 1998. The maturing of capitalist agriculture: farmer as proletarian. Monthly Review 50(3):7284.

Lindholm, C. 2008. Culture and authenticity. Malden, Oxford, and Victoria: Blackwell Publishing.

Lobo, J., and M. Quirico Jiménez. 2007a. Ampliación de conceptos. La Nación. October 31 2007. San José, Costa Rica.[accessed 1 May 2011] http://wvw.nacion.com/ln_ee/2007/noviembre/16/opinion1317913.html

Lobo, J., and M. Quirico Jimenez. 2007b. Patentes de plantas. La Nación. September 4 2007. San José, Costa Rica.[accessed 1 May 2011] http://wvw.nacion.com/ln_ee/2007/septiembre/04/opinion1227369.html

Merino del Rio, J. 2008. Costa Rica: Agenda de implementación del TLC: Terminan como comenzaron...mintiendo. Biodiversidad en América Latina. [accessed August 30 2008] http://www.biodiversidadla.org/content/view/full/42843.

Ministerio de la Agricultura y Ganadería. 2010. Reglamento de la Ley de Protección de las Obtenciones Vegetales. La Gaceta 6:42-46.

Murillo, A., and I. Venegas. 2007. TLC ratificado en las urnas. La Nación. 8 October 2007.San José, Costa Rica.[accessed 1 May 2011] http://wvw.nacion.com/ln_ee/2007/octubre/08/pais1264014.html

notlc.com. 2007. Frauderendum: TSE fue el cómplice directo del régimen de los Arias al permitir el irrespeto a la tregua electoral. [accessed August 30 2008] http://www.notlc.com/. 
Paley, J. (ed.) 2008. Democracy: anthropological approaches. Santa Fe: School for Advanced Research Press.

Peet, R., and M.J. Watts (Eds.). 1996. Liberation ecologies: environment, development, social movements. 1st edn. New York: Routledge.

Quirós O., W., and O. Carrillo A. n.d. La importancia del insumo semilla de buena calidad. Oficina Nacional de Semillas.[accessed August 30 2008] http://www.ofinase.go.cr/htm/publicaciones.htm.

RAFI. 2000. Mexican bean biopiracy: US-Mexico legal battle erupts over patented "Enola" bean Synthesis/Regeneration 22.[accessed 1 May 2011] http://www.greens.org/s-r/22/22-21.html

Rattray, G.N. 2002. The Enola bean patent controversy: biopiracy, novelty and fish-and-chips. Duke Law and Technology Review 8.

Red de Coordinación en Biodiversidad. 2004. El equipo negociador de COMEX incumple su palabra y traiciona los procesos de discusión legislativa nacional: el caso de la propiedad intelectual sobre plantas. San José, Costa Rica: Red de Coordinación en Biodiversidad.

Red de Coordinación en Biodiversidad. 2007. Exposición UPOV - proyecto ley de obtenciones vegetales 1 \& 2. San José, Costa Rica: Red de Coordinación en Biodiversidad.

Red de Coordinación en Biodiversidad. 2008. Proyecto de ley de semillas: Tiro de gracia para la agricultura nacional San José, Costa Rica: Red de Coordinación en Biodiversidad. [accessed August 30 2008] http://tlc-no.blogspot.com/2008/08/proyecto-de-ley-de-semillas-tiro-de.html.

Roa-Rodriguez, C., and T. Van Dooren. 2008. Shifting common spaces of plant genetic resources in the international regulation of property. The Journal of World Intellectual Property 11(3):176-202.

Rodriguez, S. 2008. Resistance to UPOV and the privatisation of life in Costa Rica. GRAIN Bio-IPR. 25 April 2008.

Saborio, F., and A. Brenes. 2005. Report on plant breeding and biotechnology capacity survey: Costa Rica. Rome: FAO.

Salazar, R., N.P. Louwaars, and B. Visser. 2007. Protecting farmers' varieties: new approaches to rights on collective innovations in plant genetic resources. World Development 35(9): 1515-1528.

UPOV. 2002. The notion of breeder and common knowledge in the plant variety protection system based upon the UPOV convention Geneva: UPOV. p 8.

UPOV. n.d. International union for the protection of new varieties of plants. [accessed August 30 2008] http://www.upov.int/index_en.html.

US Embassy San Jose. 2008. Another year, another referendum? Wikileaks La Nación. [accessed June 15 2011] http://161.58.182.33/Generales/Subsitios/Investigacion/2011/WikiLeaks/EntregaA/WIKILEAK136252 .aspx.

US Embassy San Jose. 2009. Yes, it is really over. Wikileaks. La Nación. [accessed June 15 2011] http://www.nacion.com/2011-03-20/Investigacion/Relacionados/N20AGUAS/WIKILEAK186538.aspx.

van Dooren, T. 2008. Inventing seed: The nature(s) of intellectual property in plants. Environment and Planning D: Society and Space 26:676-697.

Verdery, K., and C. Humphrey (eds.) 2004. Property in question: value transformation in the global economy. Oxford and New York: Berg.

Villalobos, C. 2007a. No 55\%, sí 43\% entre electores decididos a votar. La Nación. 5 October 2007. San Jose, Costa Rica.[accessed 1 May 2011] http://wvw.nacion.com/ln_ee/2007/octubre/03/pais1263817.html

Villalobos, C. 2007b. TLC ratificado en las urnas. La Nación. 8 October 2007 San Jose, Costa Rica. p 4 A.

vom Brocke, K., A. Christinck, E.Weltzien, T. Presterl, and H.H. Geiger 2003. Farmers' seed systems and management practices determine pearl millet genetic diversity patterns in semiarid regions of India. Crop Science 43:1680-1689.

Wilson, E. 2008. US patent office rejects company's claim for bean commonly grown by Latin American farmers. Burness Communications. [accessed August 30 2008] http://www.eurekalert.org/pub_releases/2008-04/bc-upo043008.php.

Wolf, E. 1972. Ownership and political ecology. Anthropological Quarterly 45(3):201-205.

Yao, S. 2010. True origins of widely used potato germplasm revealed. Agricultural Research 58(5):22.

Zueras, D. 2010. Cracks in Costa Rica's green image. Tierramerica. [accessed September 10 2011] http://www.tierramerica.info/nota.php?lang=eng\&idnews=3538. 


\begin{abstract}
Costa Rica's entry into the Central American Free Trade Agreement (CAFTA) was hotly contested and the subject of a national referendum. For activists opposing the treaty, questions of 'privatizing seeds' through imposing intellectual property rights were among the main concerns raised by the treaty, as one requirement of CAFTA was signing the international Convention on Plant Variety Protection known as UPOV. The threat to farmers' seeds in Costa Rica and many other parts of the world is more complicated than being a clear-cut issue of privatization. Struggles for control over seeds are a crucial part of the political economy of agriculture that are grounded in debates over the significance of the physical and social properties of seeds as a natural resource. This article explores how debates over intellectual property rights to seeds confound simple distinctions between public domain and private property, and the implications for agricultural genetic diversity. Moreover, through the story of Costa Rica's engagement with CAFTA and UPOV, I contemplate the broader effects of the free trade paradigm on reconfiguring ideas not only of property but also of personhood and democracy. I will argue that through reconfiguring the boundary between the public domain and private property in the realm of seeds, recent intellectual property trends also reinscribe the definition of farmers along pre-defined class lines. Through their actions, groups involved offer competing visions of how a local resource should be defined and internationally connected; these visions can be understood as competing visions of political ecology in practice.
\end{abstract}

Keywords: Costa Rica, CAFTA, UPOV, intellectual property, seeds

\title{
Résumé
}

L'entrée du Costa Rica dans l'Accord de libre-échange d'Amérique centrale (CAFTA) a été vivement contestée et fait l'objet d'un référendum national. Pour les militants opposés à l'accord, les questions de «privatisation des semences» en imposant des droits de propriété intellectuelle ont été parmi les principales préoccupations soulevées par l'accord, comme une exigence de la CAFTA a été la signature de la Convention internationale sur la protection des obtentions végétales connu sous le nom UPOV. La menace pour les semences au Costa Rica et ailleurs est plus compliqué d'être une question de la privatisation. Les luttes pour le contrôle des semences sont un élément crucial de l'économie politique de l'agriculture qui sont mis à la terre dans les débats sur l'importance des propriétés physiques et sociales des semences. Cet article explore la façon dont les débats sur les droits de propriété intellectuelle peut confondre les distinctions simples entre domaine public et propriété privée, et les implications pour la diversité génétique agricole. En outre, à travers l'histoire de l'engagement du Costa Rica avec le CAFTA et l'UPOV, je contemple les effets plus larges du paradigme de libre-échange sur la reconfiguration des idées non seulement de la propriété, mais aussi de la personnalité et la démocratie. Je soutiendrai que, grâce à la reconfiguration de la frontière entre le domaine public et propriété privée, les récentes tendances de propriété intellectuelle aussi définir des types d'agriculteurs le long des lignes de classe. Par leurs actions, les groupes impliqués offrent des visions concurrentes de la façon dont une ressource locale doit être définie et globalement connecté; ceux visions peuvent être compris comme des visions concurrentes de l'écologie politique dans la pratique.

Mots-clés: Costa Rica, le CAFTA, l'UPOV, la propriété intellectuelle, les semences 


\section{Resumen}

El ingreso de Costa Rica al Tratado de Libre Comercio de Centro América (TLCAA, por sus siglas en español) fue cuestionado de manera acalorada y tema de un referendo nacional. Para los activistas que se oponen al tratado, las cuestiones de "privatizar las semillas' mediante la imposición de derechos de propiedad intelectual estaban entre los temas principales surgidos por el tratado, ya que un requisito del TLCCA era firmar el Convenio Internacional para la protección de Nuevas Variedades de Plantas conocido como UPOV. Sin embargo, la amenaza en contra de las semillas de los agricultores en Costa Rica y muchas otras partes del mundo es más complicada que el tema bien definido de la privatización. La lucha por el control de las semillas es una parte decisiva de la política económica agrícola que se basa en debates sobre la importancia tanto de la propiedad física como social de las semillas, vista como un recurso natural. Este artículo investiga cómo los debates sobre los derechos de propiedad intelectual de las semillas complican las simples diferencias entre el dominio público y la propiedad privada y las implicaciones para la diversidad genética agrícola. Por otra parte, a través de la historia del compromiso que Costa Rica tiene con CAFTA y UPOV, yo contemplo los efectos generales del paradigma del libre tratado sobre la reconfiguración de ideas no únicamente de propiedad, sino también de calidad humana y de democracia. Plantearé que mediante la reconfiguración de los límites entre el dominio público y la propiedad privada en el ámbito de las semillas, las recientes tendencias sobre la propiedad intelectual también reinscriben la definición de los agricultores en las líneas de clase previamente definidas. A través de sus acciones, los grupos involucrados ofrecen visiones participativas sobre la manera en que un recurso local debe definirse y conectarse a nivel internacional; estas visiones pueden entenderse como visiones participativas de ecología política en práctica.

Palabras clave: Costa Rica, CAFTA (TLCCA), UPOV, propiedad intelectual, semillas 